\title{
ULOGA POLITIČKE PROPAGANDE U DESTRUKCIJI USTAVNOG UREĐENJA REPUBLIKE BOSNE I HERCEGOVINE U TOKU AGRESIJE 1992 - 1995. GODINE
}

\section{Sažetak}

Rad predstavlja analizu uloge političke propagande u destrukciji ustavnog uređenja Republike Bosne i Hercegovine u toku agresije 1992 - 1995. godine. Namjera autora je sadržana u ideji da se osvijetli neoružani vid agresije na Republiku Bosnu i Hercegovinu i način suprotstavljanja istoj. $U$ radu se obraduju modeli primjene političke propagande $u$ destruiranju ustavnog uredenja $\mathrm{RBiH}$.

Ključne riječi: Republika Bosna i Hercegovina, politička propaganda, destrukcija, agresija

Uticaj na ljude preko odgovarajućih medija s ciljem mijenjanja njihovih stavova i ideja, terminološki se određuje kao propaganda. Ona je takva da se mora posmatrati u tijesnoj povezanosti sa ideologijom koja $u$ sebi nosi gotove i precizirane stavove, vrijednosti sračunate na usmjeravanje ponašanja čovjeka $i$ njegovu odanost ovoj ili onoj ideji. Zato propagandu više možemo posmatrati kao oružje prodora odredene ideologije u svijest što većeg broja recipijenata. ${ }^{1}$ Ovakav odnos ideologije i političke propagande spram dominantne matrice društvenih vrijednosti jeste faktor zbog koga je potrebno analizirati političku propagandu kao djelovanje koje ima za cilj sadržaj političkog karaktera. $^{2}$

\footnotetext{
${ }^{1}$ Besim Spahić, Kontroverze propagandnog djelovanja, NIŠRO Oslobođenje, Sarajevo, 1987. g., str. 92.

${ }^{2}$ Damir Kukić, Politička propaganda, Weling SD, Zenica, NIPP Naša riječ, Zenica, Zenica, 2004. g., str. 14.
} 


\section{Ciljevi agresorske političko-propagandne djelatnosti}

Krajem osamdesetih godina XX vijeka ekonomski i politički prostor bivše SFRJ stajao je pred zahtjevom za transformacijom društva u cjelini. Međutim, umjesto očekivane demokratizacije društva u cjelini, došlo je do njegove destrukcije kroz primjenu ranije isplaniranog stvaranja dva velikodržavna projekta (srpskog i hrvatskog) uz pomoć elitnih naučnih i vjerskih krugova. U programskim dokumentima Načertanije i Memorandum SANU utemeljena je ideološka i politička matrica velikosrpske propagande u agresiji na $\mathrm{R} \mathrm{BiH}$.

Srpska pravoslavna crkva nije bila samo ideolog i logistika velikodržavnom srpskom projektu, nego i svjedok ali i saučesnik u minulom ratu. Ona je pružala duhovnu logistiku ratnim vođama bivajući tako i njenim akterom. Tamo gde se prospe srpska krv i gde padnu srpske kosti, to mora biti srpska zemlja, kazivao je vladika Nikanor. Nama je vrhovni komandant patrijarh Pavle, izjavljivao je na to Željko Ražnatović Arkan još oktobra 1991. godine. Jasno je da drugog puta nije bilo. Tako je sada i nama nametnut rat. Zato je taj naš rat pravedan, jer je odbrambeni. Ne napadački ni osvajački, zaključio je Patrijarh Pavle, u intervjuu za list Duga u aprilu 1999. godine.

Posebno važno je bilo odrediti ciljeve velikosrpske propagande i na njima trajno angažovati medije zbog njihove moći da utječu na kreiranje slike stvarnosti i da proizvode stvarnost. Njihov je zadatak bio da proizvedu, definiraju i situiraju problem u srpsko nacionalno pitanje dramatizirajući konkretne događaje. Tako je na suptilan medijski način pripreman genocid nad Bošnjacima prihvatljiv srpskom stanovništvu tako što su Bošnjake depersonalizirali, istovremeno ih predstavljajući posebnom opasnošću i vežući ih na specifičan način za kosovski mit.

Procjenjujući vrstu i snagu potencijalnih prepreka za ostvarivanje projekta velike Srbije, njeni ideolozi su kao težišnu označili onu koja se odnosila na neraspoloženje naroda prema njihovim idejama. Zato su sebi postavili kao prvi cilj da pokrenu Srbe i Crnogorce da ulažu napore u agresiji koja se izvršava genocidom i zločinima. Pred njima se tada otvorio novi problem koga su definirali kao svoj drugi cilj usmjeren na 
umanjenje otpora naroda ugroženih velikosrpskom agresijom i na kraju su morali pristupiti uvjeravanju međunarodne javnosti $u$ ispravnost velikosrpske političke i vojne strategije.

Kako bi lakše otpočeli sa realizacijom prvog cilja, od Bošnjaka je stvoren negativan lik kojeg je karakteriziralo poistovjećivanje sa Turcima u nacionalnom i historijskom smislu, te negativna identifikacija $u$ religijsko-duhovnom smislu. Kao takvog, moralo ga se uništiti poredeći ga sa stranim neprijateljskim tkivom u domaćem organizmu, ali i uništiti tragove njegovog materijalnog postojanja. Tako su dehumanizirani Bošnjaci bili kroz medijsku hajku pripremljeni za odstrel. Sve je to bilo stavljeno u ambijent tamnog vilajeta, prostora izvan evropskih i svjetskih kulturnih utjecaja. Takav prostor je predstavljen kao onaj koji ne posjeduje državni, povijesni i kulturni identitet te zaokružen proizvoljnim granicama, prostor u kojem je vjerskoj grupi - muslimanima - od strane komunista darovana nacija.

Pošto muslimani teže svakoj vrsti dominacije, od $\mathrm{BiH}$ je napravljen problem koga treba konačno riješiti njenim uništenjem i podjelom na srpske i hrvatske nacionalne prostore te pripajanjem istih Hrvatskoj, odnosno Srbiji. Zato su pokrenuli široku propagandu s ciljem da ona na dnevnoj bazi dopire, ne samo do svih Srba i Crnogoraca, nego i do njihovih potencijalnih saveznika, kako bi ih gurnuli u realizaciju različitih akcija sa krajnjim epilogom činjenja zločina nad Hrvatima i Bošnjacima. Zamisao je bila da se ta aktivnost protegne na šire mase u zemlji i svijetu $s$ ciljem njihovog animiranja za brže ostvarivanje velikodržavnih srpskih ciljeva. Uz to je trebalo utjecati na smanjenje potencijalnog otpora ugroženih naroda, ali i preduprijediti potencijalnu akciju međunarodne zajednice.

Pomenuti ciljevi su bili komplikovani za ostvarenje iz najmanje dva razloga: teško je bilo sakriti počinjene zločine nad Bošnjacima i spriječiti prevashodno njihovo odbrambeno organiziranje $u$ oformljenom patriotskom frontu. Osim toga, potvrde o uspješnosti pruženog otpora su dobijene u smislu spoznaje o njima od relevantnih faktora u okviru međunarodne zajednice, a svjetsko javno mnijenje je bilo zgroženo činjenicom oživljavanja najcrnjih oblika srpskog fašizma krajem 
dvadesetog stoljeća. Uništenje političke posebnosti i fizičkog opstanka Bošnjaka postavljeno je kao radikalan cilj agresije na $\mathrm{R} \mathrm{BiH}$. Radikalnost postavljenog cilja agresije maksimalno je radikalizirala ukupnu psihološko-propagandnu djelatnost, dovodeći ih do nivoa međusobne uslovljenosti. To je za posljedicu imalo ogromno stradanje Bošnjaka od različitih sadržaja, formi, snaga i sredstava koja su angažovana za provođenje psihološko-propagandne djelatnosti. Iz tog razloga su Bošnjaci ubijani na mnoštvo zvjerskih i ljudskom razumu teško shvatljivih načina uz zatiranje bilo kakvih tragova njihovog postojanja. Tada je bilo opravdano primijeniti svako raspoloživo sredstvo radi ostvarenja postavljenog cilja. Na prostoru okruga Bihać, Bošnjaci su doživjeli genocid, urbicid, kulturocid. Činjenje tih zločina podsticalo je činjenje novih zločina, kao znaka ohrabrenja $\mathrm{i}$ istrajnosti do konačnog istrebljenja Bošnjaka. Osim toga, ti zločini su ulijevali optimizam čitavom srpskom narodu da ć se postići ukupni ciljevi agresije $s$ namjerom da se istraje u naporima koje nalaže agresija. Računali su i na efekt straha među nesrbima, koji bi za posljedicu imao paniku i osjećaj uzaludnog pružanja otpora.

Prepoznatljivo je nastojanje ideologa velike Srbije da svoje ciljeve ostvaruju upotrebom strategijske i propagande taktičkog karaktera kojom su nastojali da zahvate što je moguće veći prostor djelovanja i koja je trajala znatno duže nego sama agresija. Očitovala se u stvaranju straha i nesigurnosti za život i opstanak u $\mathrm{BiH}$, čime bi se intenziviralo iseljavanje Bošnjaka i time smanjio potencijalni borbeni korpus. To je bio razlog da su mnogi Bošnjaci vođeni instinktom samoodržanja, i ne prepoznavajući pravi karakter stvorene krize, odlazili na razne strane svijeta.

Velikosrpska politika je upotrijebila velikohrvatsko negativno raspoloženje (prisiljavanje Bošnjaka na iseljavanje iz $\mathrm{BiH}$, pridobijanje dijela njih za HVO, sprječavanje konstituiranja $A R B i H$ itd.) za svoje ciljeve. Mada su ideološke i političke osnove velikosrpske i velikohrvatske agresije na $\mathrm{RBiH}$ različite $\mathrm{i}$ međusobno suprotstavljene, po osnovu radikalno postavljenih ciljeva tih politika koje se međusobno isključuju, Milošević i Tuđman su sporazumom afirmirali politički kompromis $s$ ciljem nestanka BiH i Bošnjaka u njoj. Zato je bitno kazati da su 
velikosrpski i velikohrvatski psihološko-propagandni metodi i sadržaji borbe protiv $\mathrm{BiH}$ i Bošnjaka bili isti. Pri tome je velikohrvatska propaganda stvarala pretpostavke za pojavu Abdićeve propagande u funkciji velikosrpske propagande, gdje je on izvršavao zadatke iz dogovora Tuđman - Milošević.

$\mathrm{Na}$ prostorima Cazinske krajine, po zamislima ideologa iz Beograda, trebalo je formirati APZB preko koje bi se na ovom prostoru isključio svaki utjecaj Alije Izetbegovića i Franje Tuđmana, iz razloga njegovog velikog operativno-strategijskog značaja za velikodržavni srpski projekt. Njeno instaliranje i egzistiranje bilo je značajno i iz razloga formuliranih ženevskim sporazumima po kojima ta teritorija, kao autonomna u odnosu na vlast u Sarajevu, ostaje u sastavu Bosanske Republike u Uniji Republika BiH. Abdićeva politika je prikazivana kao vitalni srpski interes. Međutim, ljudi iz RSK su masovno bili protiv toga da im djeca ginu za, kako su govorili, šverc $i$ Turke. Vojnici su smatrali da treba pustiti Muslimane (Bošnjake) da ratuju međusobno, te da Srbi ne treba da se bore za Turke. Beograd je bio ubijeđen da će Fikret Abdić ovladati cijelom Cazinskom krajinom uz pomoć policijskih i vojničkih formacija iz Srbije. Nakon toga, Abdićeva republika je trebala pripasti Hrvatskoj, što bi Tuđman prihvatio i zaposjednute dijelove RS-a vratio Miloševiću, odnosno Karadžiću. Mene ne zanima Abdićeva republika, zanima me pola $B i H$, izjavit će tada Milošević. ${ }^{3}$

\section{Principi organizacije i vođenja političke propagande}

Planska, organizirana propaganda je bila i ostala najmoćnije sredstvo ostvarivanja velikodržavnih aspiracija, ne samo nama susjednih, nego $i$ nekih evropskih zemalja sa trajnim osobinama: agresivnosti, sinhroniziranosti i istrajnosti uz korištenje religije, kulture i masovnih medija. Politička propaganda funkcioniše u skladu sa nekoliko principa prema kojima se ona razlikuje prema sadržajima i modelima drugih vrsta propagande. Razumljivo da postoji konkretno klasificirana linija njihove

\footnotetext{
${ }^{3}$ Hrvoje Šarinić, Svi moji tajni pregovori sa Slobodanom Miloševićem, 1993 - 1995., Globus, Zagreb, 1999. g., str. 46.
} 
distinkcije. Gledano povijesno, principi organizacije i vodenja političke propagande nisu se promijenili. Neki od njih su samo modificirani, ali se suštinski nisu promijenili. ${ }^{4}$

Principom simplifikacije pokušavao se sažeti cjelokupan segment poruka poput programa političkih partija u Srbiji, Hrvatskoj i $\mathrm{BiH}$ (sa smjernicama iz Srbije i Hrvatske), ili doktrina određenih velikodržavnih ideologija prema $\mathrm{BiH}$ i iskazati u jednoj poruci jasnog i kratkog sadržaja. U tu svrhu su odabrane suptilne poruke. Velikosrpski koncept je iznjedrio poruku Svi Srbi u jednoj državi, kako bi mobilizirao i jednosmjerno orijentirao sve njene recipijente. Djelujući prema Bošnjacima, opredjeljenje je bilo da je najprihvatljivija poruka: Bošnjaci su Srbi islamske vjeroispovijesti, a u pogledu $\mathrm{BiH}$ : Bosna = srpska zemlja. Velikohrvatski koncept je promovirao poruku: Bošnjaci su hrvatsko cvijeće, kako bi ih predestinirao za svoje ciljeve. Sljedbenici Fikreta Abdića su se pridružili ovim nosiocima dvaju velikodržavnih projekata svojom porukom: Ovo je babina zemlja, aludirajući pri tome na svoga vođu Fikreta Abdića zvanog Babo, koji je bio u funkciji tih dvaju projekata.

Uz pomoć principa reprodukcije neprijatelja izazivana je od strane velikodržavnih srpskog i hrvatskog projekta odbojnost prema $\mathrm{BiH}$, probošnjačkim političkim opcijama i probošnjačkim i probosanskim programima, uz istovremeno ostvarivanje homogenizacije svojih pristalica na bazi straha i ksenofobičnosti. Režim Slobodana Miloševića je tokom ratova u $\mathrm{BiH}$ za neprijatelja srpstva proglašavao mudžahedine, titoiste, ustaše do arapskih zemalja, SAD i Njemačke. Istovremeno je isti princip primjenjivao i prema pripadnicima svog režima nazivajući neprijateljem srpskog naroda sve one političke subjekte i pojedince koji su bili protivnici njegovog političkog velikodržavnog srpskog projekta. Abdićevi trabanti su išli tako daleko da su prilikom bježanja pred jedinicama Petog korpusa govorili onima koji nisu htjeli da bježe, da će im korpusovci sve popaliti, porušiti i raznijeti, a njih ubiti.

${ }^{4}$ J. M. Domenach, La propaganda politique, PUF, Paris, 1981. g.; Prema Besim Spahić, 1987. g., Kontroverze propagandnog djelovanja, Sarajevo, NIŠRO Oslobodenje, str. 104. 
Služeći se principom preuveličavanja, nosioci ova dva velikodržavna projekta su u organizacionom smislu, koristeći raspoloživa sredstva, vodili političku propagandu. Pritom su izdvajali samo aspekt koji je govorio o pozitivnoj strani onoga što su oni radili, nastojeći time dobiti podršku ne samo na domaćem, nego i na stranom prostoru animirajući svoje potencijalne pristalice. Srbija je dugo vremena nakon disolucije SFRJ prikazivala sebe kao jedinu sljednicu te tadašnje države, kako bi time kod nekadašnjih prijatelja te države u svijetu obezbijedila podršku da se ona sačuva i zaštiti. Pri tome su se domaćini pred vlastitom i inostranom javnošću pokušavali prikazati kao osobe od formata. Primjer za to je Fikret Abdić koji je volio govoriti tokom 1993/1994. godine da je on primio u posjetu lorda Dejvida Ovena i sa njim razgovarao o problemima $\mathrm{u} \mathrm{BiH}$, naglašavajući prestižne rezultate koje je postigla $A P Z B \mathrm{u}$ dotadašnjem periodu.

Stalno ponavljanje i ukazivanje na ugroženost srpskog i hrvatskog naroda, a poslije i muslimanskog stanovništva Fikreta Abdića od strane Bošnjaka, te naglašavanje da su oni Srbi islamske vjeroispovijesti, odnosno da su oni Hrvatsko cvijeće, stvaralo je efekt intenziviranja poruka. Istovremeno su one dopunjavane i dublje koncentrisane u svijest javnosti. Ovaj princip je baziran na činjenici da se na stavove, mišljenja i ponašanja može djelovati samo trajnim, intenzivnim i optimalnim pobuđivanjem unutar komunikacijskog procesa.

Svjesni potrebe uspostave vrijednosnog okvira unutar kojeg mora postojati podjela na poželjno ponašanje unutar grupe, kolektiva, mase, nacije i struktura nagrada za takvo ponašanje i nepoželjnog ponašanja sa raznim kaznama, kreatori dvaju velikodržavnih koncepata su insistirali i na principu jedinstvenosti, odnosno integriranosti. Tako je kod prvopomenutih za homogenizaciju nacije iskorišten poziv na jedinstvo naroda radi odbrane srpstva, a kod drugih poziv za jedinstvo u odbrani vjekovnih hrvatskih prostora. Abdićevi trabanti su se opredijelili u pogledu ovoga principa za varijantu zaštite demokratije Babine države.

Kod opredjeljenja za princip idolopokretača ili pravila transfuzije, u prvom planu je bila ideja kreiranja savremenih propagandnih poruka čija se percepcija, razumijevanje i usvajanje bazira na arhetipskim uzorima i 
mitskim transpozicijama svojstvenim čovjeku. Time se prirođeni mitovi, aveti i iracionalno područje ljudskog djelovanja konkretizuju u moderne propagandne ciljeve. Takav mitološki predznak je primjetan npr. kod velikosrpske propagande $\mathrm{u}$ formi nebeskog naroda koji je pobjede izvojevao svugdje gdje se je pojavljivao, počev od Kosovskog boja. Istovremeno je velikohrvatska propaganda taj princip primjenjivala na hiperboliranju ideje o misiji hrvatske kulture i države $\mathrm{u}$ iniciranju procesa europeizacije balkanskih naroda. Fikret Abdić je prikazivan kao osoba koja je nastavljala kontinuitet djelovanja epske ličnosti sa ovog kraja - Muje Hrnjice.

Kontrapropagandno djelovanje kao princip djelovanja političke propagande je usmjereno ka defavorizovanju bošnjačke propagande, utvrđivanjem njenih loših strana uz potenciranje sopstvenih dobrih. Reprodukcijom laži i dezinformacija uz njihovo preuveličavanje stvara se osjećaj straha ili animoziteta prema Bošnjacima protiv kojih je i usmjerena propaganda. Od strane tvoraca velikosrpskog projekta bilo je uočljivo ismijavanje Bošnjaka, pa je jednom prilikom voditelj srpskog Dnevnika, Risto Đogo, doveo magarca u studio i tako ismijavao Aliju Izetbegovića. Osim toga, koristili su karikature, proturali glasine i pričali viceve na račun državnog rukovodstva, države $\mathrm{BiH}$ i Bošnjaka, što je u ratnoj propagandi poznato da se čini.

\section{Metode i sredstva političko-propagandnog djelovanja na destruiranju ustavnog uređenja $\mathrm{R} \mathrm{BiH}$}

Različite metode služe za stvaranje konkretnih emocionalnih stanja kod pojedinaca i grupa, djelujući putem emocija na njihovu svijest i stvaranjem uslova za željeno ponašanje. $U$ tom smislu pokušalo se djelovati uoči i početkom rata ubjeđivanjem, pri čemu je glavni faktor bila činjenica neravnomjernog odnosa snaga i naoružanja u kome se nalazio Peti korpus, koliko spram bivše JNA, toliko i spram vojnih i policijskih snaga Srbije, te kolaboracionističkih snaga iz $\mathrm{BiH}$ stacioniranih u Bihaću i na prostoru oko okruga Bihać.

Sličnim metodom su se služili i predstavnici FRABAT 3 na čelu sa pukovnikom Žan Šarlom Lemijeom (kontingent francuske vojske 
stacioniran jedno vrijeme u Bihaću tokom rata), kada su tokom 1994. godine tražili od komandanta Petog korpusa da se izvrši demilitarizacija sigurnosne zone UN Bihać $\mathrm{u}$ duhu tada vođenih međunarodnih pregovora o miru u $\mathrm{BiH}$, gdje su agresorske snage bile stegle obruč oko Bihaća i da se razoruža ova vojna formacija.

Opkoljenom stanovništvu okruga Bihać nuđeno je identificiranje sa osobama poput Fikreta Abdića, tada afirmisanom ličnošću u privrednom smislu i još, k tome, članu Predsjedništva RBiH. Postizanjem visokog stepena identifikacije propagandnih ciljeva sa očekivanjima Srba u Srbiji i $\mathrm{BiH}$, velikosrpski i velikohrvatski centri moći su uspjeli uvjeriti veliki broj Srba u krivicu nesrba te da su oni jedini zaštitnici interesa srpskog naroda.

Izazivanje pozitivnih i negativnih osjećaja kao metod ima za osnovu podsticanje i stvaranje mržnje. To je značilo prevashodno primjenu taktike zavadi pa vladaj, tako što je Bošnjacima srpska propaganda prvo nametala stanovište da su oni i Srbi braća po krvi koje samo razlikuje vjera. Ubrzo je izvršena nadogradnja istog time da su Bošnjaci izdali pradedovsku veru i da su oni poturice koje treba krstom i oružjem vratiti na pravi put. Polazeći od toga da je izdaja najteži grijeh u sistemima vrijednosti svakog naroda, onda onaj ko je to počinio mora biti najžešće kažnjen.

Imajući u vidu to da je strah osnovna ljudska emocija koja utječe na čovjekovo ponašanje uopće, često je korišteno zastrašivanje kao metod. Strah od smrti često je bio jedan od motiva suprotstavljanja agresoru s ciljem njegovog neutralisanja i eliminisanja njegovih uzroka. Na toj tački se javlja zastrašivanje kao metod kojim se vrši manipulacija masama. Često su u tom smislu korištene rakete zemlja-zrak Volhov i Orkan po našim vojnim i civilnim lokacijama, jer se njihovo djelovanje željelo prikazati kao djelovanje nepoznatih oruđa i kod branilaca izazvati strah.

Metod prilagodavanja istine je korišten s ciljem oblikovanja poruka i informacija kako bi se obezbijedilo očekivano ponašanje onih kojima su takvi sadržaji upućeni. Polazeći od sklonosti ljudi da sami transformišu informaciju kada djeluju u funkciji posrednika, prilagođavajući je svojim 
interesima i potrebama ako njima odgovaraju kao takve - u prvi plan su stavljani naglašeni detalji informacije. Najčešće se to odnosilo na predstavljanje ogromnih gubitaka Petog korpusa, na što su trebali nasjesti manje obrazovani ljudi. Određene informacije su dopunjavane, pa je tako prilikom realizacije akcije Tigar-Sloboda 94 Abdićeva strana govorila o Atifu Dudakoviću koji je pobjegao iz zemlje ostavljajući svoje borce. Uprošćavanjem informacija željelo se djelovati na crno-bijeli odnos u korištenju istih, pa je nuđen sadržaj oko istinitog događaja vezanog za ženidbu jednog od članova komande Petog korpusa prilikom čega se razbacivalo sa hranom i pićem, a borci nisu imali šta da jedu.

Postupak iskrivljavanja sadržaja i konstruiranja od izmišljenih elemenata je ponudio nebulozu tipa Muslimani su granatirali sami sebe u Sarajevu na Markalama. Na udaru su bili Sandžaklije u ARBiH, poput komandanata Sefera Halilovića i Ramiza Drekovića što se najočitije prepoznavalo kroz istupe Abdićevih snaga da se iz sastava Petog korpusa moraju ukloniti svi nekrajišnici, a posebno Sandžaklije koji su zauzeli ne samo pozicije u vojsci, nego i u ostalim društvenim djelatnostima i državnim organima.

Od više metoda karakterističnih za političko djelovanje, tvorci velikodržavnih (srpskog i hrvatskog) projekata su maksimalno koristili metod transformacije ili prekrajanja činjenica. Cilj prekrajanja činjenica je izazivanje straha i podozrenja od mogućih posljedica određenog ponašanja auditorijuma. O tome vrlo interesantno pišu Koen i Risman: Najteže je kod pojedinih političkih propagandista pokušati predvidjeti prošlost. ${ }^{5}$ Ovim se postupkom mijenjaju činjenice s ciljem obezbjeđivanja povoljne slike o vlastitom političkom djelovanju u sadašnjosti.

Djelo čuvenog srpskog slikara Uroša Predića (1857 - 1953.) pod nazivom Siroče na majčinom grobu, novinari Večernjih novosti iz Beograda su ratnohuškački zloupotrijebili predstavivši ga tokom 1994. godine publici kao fotografiju dječaka na grobu oca, majke $i$ ostale rodbine koju su u ofanzivi pobili Muslimani. Dečaka sa slike u meduvremenu usvojila je jedna porodica iz Zvornika i sada je on učenik prve godine srednje vojne

5 Filip Koen i David Risman, Srpski tajni rat, propaganda i obmana istorije, Ljiljan, Sarajevo, 1996. g., str. 155. 
škole. Dječak i fotografija uopće nisu postojali. To je bila umjetnička slika.

U ovo svakako spada i pokušaj velikohrvatske propagande da promovira taj projekat tako da Hrvatsku predstavi kao predziđe kršćanstva s ciljem sticanja simpatija u Evropi. Istovremeno su planirali racionalizaciju i opravdanost svojih pretenzija ka $\mathrm{BiH}$.

Uzimajući jezik za osnovno sredstvo komuniciranja među ljudima, možemo kazati da je on i osnovno sredstvo propagande. Manipuliranje jezikom u propagandi je planski, osmišljen postupak pomoću koga autor informacije utječe na ljude kako bi se obezbijedili uslovi za realizaciju interesa tog čovjeka ili tih ljudi. Time se čovjek dovodi u podređen položaj čime se modificira i usmjerava isključivo njihova praksa. ${ }^{6}$ Tako se unificira mišljenje uz marginaliziranje kritičkog mišljenja i slobode svijesti. Vlast se, pored ostalog, ostvaruje i jezičkom dominacijom, pa je otuda bila prisutna kovanica iz palete velikodržavnih srpskih termina pričaj, bre, srpski da te ceo svet razume.

Riječju i slikom mediji su, bivajući u funkciji tada velikodržavnih koncepata, direktno doprinosili destrukciji ustavnog uređenja $\mathrm{R} \mathrm{BiH}$. Program TV Beograd iz 1991. i 1992. godine je bio tako pravljen da su bosanski Srbi povjerovali da su ugroženi od ustaških hordi i fundamentalističkog džihada, što je po poznatom beogradskom novinaru, Milošu Vasiću, bilo isto kao kad bi Ku Klux Klan preuzeo svu TV mrežu u $S A D$.

\section{Borba protiv utjecaja agresorske političko-propagandne djelatnosti usmjerene na destruiranje ustavnog uređenja $\mathrm{R} \mathrm{BiH}$}

Tokom odbrambeno-oslobodilačkog rata 1992 - 1995. godine protiv uticaja političko-propagandne aktivnosti agresora usmjerene na destruiranje ustavnog uređenja $\mathrm{R} \mathrm{BiH}$, vođena je borba samo istinom uz naznaku da je na sceni srbijansko-crnogorska, a kasnije i hrvatska agresija,

6 Šemso Tucaković, Propagandno komuniciranje, Studentska štamparija Univerziteta Sarajevo, Sarajevo, 1999. g., str. 132. 
ponovo fašizam, da embargo postoji samo za Bošnjake i ARBiH i da se ARBiH bori za demokratsku i građansku državu. Ta borba je proizlazila iz političke osnove za suprotstavljanje agresorima i ciljeva odbrambenooslobodilačkog rata (1992 - 1995.) političke i vojne prirode. Polazeći od toga da je agresija imala totalitaran karakter koji se ogledao u primjeni svih raspoloživih snaga, sredstava, metoda i mjera radi uništenja temelja postojanja Bošnjaka i islama na prostoru $\mathrm{BiH}$, kao i ukidanje ukupnih pretpostavki za opstanak bh. države, borba protiv agresora je u sebi sadržala i borbu protiv njegove političko-propagandne djelatnosti. Ona je morala biti istrajna te kakvoćom i kvantitetom morala nadvisiti agresora $\mathrm{u}$ svakom pogledu. Tom borbom, u uslovima totalne agresije, moralo se spriječiti postizanje agresorskih ciljeva usmjerenih ne samo prema $\mathrm{ARBiH}$ i civilnom stanovništvu $\mathrm{BiH}$, nego i prema međunarodnoj javnosti i međunarodnoj zajednici.

Agresorima je posebno bilo važno da političko-propagandnom djelatnošću sakriju od međunarodne javnosti agresiju. Za ostvarenje tog nauma koristili su različite teze kojima je zajedničko ishodište bilo građanski rat $\mathrm{u} \mathrm{BiH}$. Reagirajući na to, razobličavane su te teze iznošenjem činjenica o agresiji na $\mathrm{BiH}$ od strane Srbije, Crne Gore i Hrvatske uz pomoć kolaboracionista. Istovremeno je ukazivano na kršenje principa iz Povelje UN-a, što je impliciralo odgovornost međunarodne zajednice koja je propuštala priliku da zaštiti svoju članicu i kazni agresore. $\mathrm{U}$ tom smislu nastupano je sa lepezom argumenata koji su potvrđivali aktualne političke dogovore o podjeli $\mathrm{BiH}$ između predsjednika Srbije i Hrvatske, ali i djelovanja neprijateljskih oružanih formacija prema $\mathrm{BiH}$.

Kompromitacija političkog i vojnog rukovodstva $\mathrm{BiH}$ je bila stalan cilj neprijateljske političko-propagandne aktivnosti, koji se nastojao realizirati tokom cijele agresije. Njihova osnovna teza je bila vezana za proglašavanje odluka pomenutih rukovodstava pogrešnima radi opravdavanja ispravnosti vlastitih agresorskih aktivnosti. Zato je prenošenjem i objašnjavanjem odluka i stavova najviših civilnih i vojnih organa $\mathrm{BiH}$ i njene Armije, naglašavana njihova opravdanost usmjerena na uspostavu pravednog mira na bazi očuvanja $\mathrm{BiH}$ kao države 
ravnopravnih naroda i građana koji žive u njoj. Time je ostvarivan neophodan stepen jedinstva između stanovništva, pripadnika $\mathrm{ARBiH}$ i njihovog civilnog i vojnog rukovodstva koje je (jedinstvo, op.a.) bilo brana za eventualno destruiranje sistema u cjelini. Agresori nisu imali samo za cilj praviti odvajanje branilaca $\mathrm{BiH}$ od njihovog rukovodstva, nego i da stvore ambijent za uskraćivanje podrške relevantnih faktora međunarodne zajednice pravednim i miroljubivim odlukama i stavovima bh. rukovodstva. Zato je bilo od velike važnosti na okrugu Bihać npr. sačekati smjenu Fikreta Abdića sa dužnosti člana Predsjedništva $\mathrm{BiH}$, zbog njegovog antiustavnog djelovanja usmjerenog na rušenje $\mathrm{BiH}$, kako bi se moglo vojno djelovati protiv njegovih oružanih formacija. U suprotnom - to bi bio državni udar i djelovanje protiv Ustava $\mathrm{BiH}$, jer je on bio član Vrhovne komande ARBiH čiji je sastavni dio bio i Peti korpus.

Predrasude evropskog i dijelom svjetskog formata $\mathrm{u}$ odnosu na islam su značajno otežavale borbu za međunarodnu podršku odlukama i stavovima političkog vrha $\mathrm{BiH}$. Te predrasude je maksimalno involvirala u svoju političko-propagandnu aktivnost agresorska strana predstavljajući odbrambene snage $\mathrm{ARBiH}$ kao islamske fundamentalističke snage oformljene za ugrožavanje slobode drugih naroda u regionu i šire. S tim u vezi suzbijane su takve teze kroz demokratsko, miroljubivo i pravedno političko ponašanje i djelovanje rukovodstva $\mathrm{BiH}$ koje je na tom putu bilo odlučno, pa je bilo očito cjelokupnoj svjetskoj javnosti, otvorenost $\mathrm{BiH}$. Novinari iz cijelog svijeta su na licu mjesta mogli provjeravati održivost agresorskih teza o islamskom fundamentalizmu što je naišlo na svjetsku podršku. BiH rukovodstvo nije imalo i nije htjelo ništa kriti nego pokazati samo istinu, dok je $s$ druge strane agresor imao upravo takvu potrebu, politički fundiranu unaprijed znajući da će ih to kompromitirati.

Informacije o zločinima agresora i kolaboracionista su izazvale reakcije svjetskog javnog mnijenja čime su demokratska javnost svijeta, ali i važni faktori međunarodne zajednice spoznali fašistički karakter agresorske politike prema $\mathrm{BiH}$. Upravo je to najviše pomoglo u dobivanju međunarodne pomoći raznih vidova. Spoznaje o urbicidu, kulturocidu i 
posebno sakralocidu koga je provodio agresor su sablaznule svjetsko javno mnijenje - poput paljenja Vijećnice u Sarajevu i rušenja Starog mosta u Mostaru. Ti zločini su imali svoje adrese -velika Srbija i velika Hrvatska. Rušenje mnogih džamija (npr. Ferhadije u Banjoj Luci) je izazvalo veliki gnjev svih civiliziranih nacija u svijetu, te njihovo totalno uklanjanje sa prethodne lokacije i otvaranje pijace na tom mjestu (npr. džamija u Ripču kod Bihaća), što je bilo djelo tih velikodržavnih politika.

U uslovima totalnog okruženja i agresije javljale su se mnogobrojne anomalije poput nastanka situacije koju smo identificirali kao mirnodopski sindrom. Izostanak borbenih dejstava je nekad bio planskog karaktera uz pojačanje šverca na linijama dodira od strane agresora. Prema procjeni agresora takve situacije su prekidane onda kada su smatrali da mogu ostvariti značajniji borbeni rezultat. Zato se snažno vodila široka medijska aktivnost posvećena mnogobrojnim aktivnostima na ratištu i u pozadini čime su jačani borbeni mehanizmi u djelovanju stanovništva i pripadnika Petog korpusa. Ovo je bilo posebno značajno u momentima vođenja međunarodnih mirovnih pregovora za $\mathrm{BiH}$ kada su agresori naše stanovništvo nastojali uvjeriti u opravdanost istih, naglašavajući da se tome protivi naše državno rukovodstvo. Ovo je vješto koristio Fikret Abdić kod, primjera radi, pokretanja inicijative za formiranje APZB kada je kod lokalnog stanovništva provodio anketu sa temeljnim pitanjem: Jesi li za mir?, dobijajući afirmativan odgovor (logično je da čovjek teži miru), te ga je vješto manipulirao u pravcu ostvarenja svoje osnovne zamisli.

Stalne pokušaje oko prebacivanja krivnje za izbijanje rata sa agresora na žrtvu anulirano je djelovanjem na jačanju patriotskog političkog jedinstva stanovništva i pripadnika Petog korpusa, snažeći pri tome naše diplomatske pozicije. To je kompromitirajuće djelovalo na agresorsku politiku i njen fašistički karakter, ali i imalo velikog odraza na motiviranost stanovništva da istraje u borbi do konačnog oslobođenja. Usko vezano za ovo je tumačenje uzroka rata u SFRJ i agresije na $\mathrm{BiH}$, gdje se suptilno pojašnjavala ovdašnjem stanovništvu, nekadašnjem lideru u ljubavi prema Jugoslaviji, ova problematika. Činjenice su govorile o rušenju Jugoslavije od strane ideologa velike Srbije i velike Hrvatske i 
njihovom egzistiranju na račun $\mathrm{BiH}$. Njihov stav spram te činjenice je jasno izražen u održanom referendumu za nezavisnost $\mathrm{BiH}$ koga su branili i odbranili u proteklom ratu. Naravno da su bile u potpunosti otkrivene namjere tvoraca dva velikodržavna projekta, ali i demistificira se ustaštvo i četništvo zajedno sa zločinima koje su oni počinili, kako bi se podstakle odbrambene aktivnosti naši oružanih snaga.

Pomenuto djelovanje je u velikoj mjeri doprinijelo nastanku i afirmisanju djelovanja Patriotske lige koja je bila osnova za okupljanje svih patriotskih snaga za odbranu BiH. Bivajući izrazom političkih ciljeva, ona je snažno motivirala ljude, naročito u predvečerje agresije, da se ujedine i ne dozvole odvajanje naroda od stručnih vojnih kadrova potrebnih za uspješno vođenje OOR 1992 - 1995. godine. Uz to su afirmisani maksimalno napori da se istraje - u smislu ulaganja velikih napora i žrtava u prisutnoj agresiji, usmjeravanjem ka izglednim perspektivama prisutnog rata. Alternativa u tom pravcu je vodila ka sigurnom uništenju Bošnjaka i njihovom nestanku sa zatiranjem svih tragova njihova postojanja. U totalno okruženom okrugu Bihać, odgovornost civilnih i vojnih organa vlasti je samim tim bila veća posebno spram kolaboracionističke uloge Fikreta Abdića. Optimizam tih struktura je bio baziran na izuzetno kvalitetnoj organizaciji i čvrstoj volji da se istraje u realizaciji ciljeva OOR 1992 - 1995. g. Naravno da je time izgrađena brana izazivanju defetizma, osjećaja besperspektivnosti i gušenju volje žrtvovanja za odbranu sopstvenog života i $\mathrm{BiH}$.

Izvođenje aktivnih borbenih dejstava nosilo je u sebi primjere herojstva i postizanje uspjeha nepoznatih u historiji, ali i teoriji o mogućnostima djelovanja u borbenim dejstvima. Napadni momenat u ratu je bio od velikog značaja za moral boraca čime je jačan faktor jedinstva unutar oružanih snaga $\mathrm{BiH}$. Efekti uspješno vođenih borbi su afirmisali uspješnost $\mathrm{ARBiH}$ i $\mathrm{BiH}$ u cjelini, eliminirajući efekte agresije $s$ radikalnim ciljem usmjerenom na $\mathrm{BiH}$ i Bošnjake prevashodno.

\section{Literatura:}

1. Besim Spahić, Kontroverze propagandnog djelovanja, NIŠRO Oslobodenje, Sarajevo, 1987. g. 
2. Damir Kukić, Politička propaganda, Weling SD, Zenica, NIPP Naša riječ, Zenica, Zenica, 2004. g.

3. Hrvoje Šarinić, Svi moji tajni pregovori sa Slobodanom Miloševićem, 1993 1995., Globus, Zagreb, 1999. g.

4. J. M. Domenach, La propaganda politique, PUF, Paris, 1981. g.; Prema Besim Spahić, 1987. g., Kontroverze propagandnog djelovanja, Sarajevo, NIŠRO Oslobodenje.

5. Filip Koen i David Risman, Srpski tajni rat, propaganda i obmana istorije, Ljiljan, Sarajevo, 1996. g.

6. Šemso Tucaković, Propagandno komuniciranje, Studentska štamparija Univerziteta Sarajevo, Sarajevo, 1999. g. 
Izudin Saračević, M.A.

\section{THE ROLE OF POLITICAL PROPAGANDA IN DESTRUCTION OF CONSTITUTIONAL SYSTEM IN THE REPUBLIC OF BOSNIA AND HERZEGOVINA DURING THE 1992 - 1995 AGGRESSION}

\section{SUMMARY}

The paper provides an analysis of the role of political propaganda in destruction of constitutional system in the Republic of Bosnia and Herzegovina during the aggression 1992-1995.

The author intended to highlight non-military aggression on the Republic of Bosnia and Herzegovina and corresponding modes of resistance.

The paper deals with different models of political propaganda used in destruction of constitutional system in the Republic of Bosnia and Herzegovina.

Key words: The Republic of Bosnia and Herzegovina, political propaganda, destruction, aggression 


$$
\text { الأستاذ عز الدين ساراتشيفيتش }
$$

دور الدعاية السياسية في تدمير التنظيم الدستوري لجمهورية البوسنة والهرسك

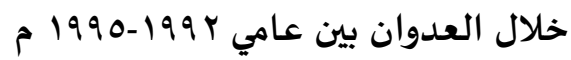

\section{الخلاصة}

يعتبر هذا البحث تحليل دور الدعاية السياسية في تدمير التنظيم الدستوري

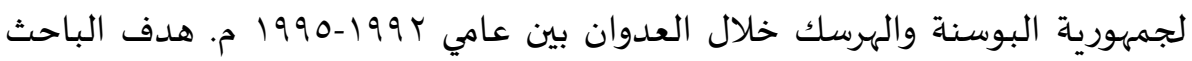

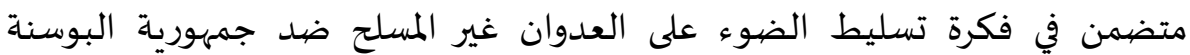
والهرسك وكيفية مواجهتها. يتناول البحث طرق تطبيق الدعاية السياسية في تدمير التنظيم الدستوري لجمهورية البوسنة والهرسك.

الكلمات الرئيسة: جمهورية البوسنة والهرسك، الدعاية السياسية، التدمير،

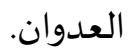

